\title{
NIGERIA'S ECONOMIC GROWTH: DO REMITTANCE INFLOWS REALLY MATTER?
}

Using quarterly data from 1977-2012, this study examines the role of remittance inflows on economic growth in Nigeria. Unlike most previous studies, we address the problem of endogeneity of the remittance variable. The pattern of remittance inflows within the periods under review suggests that the effect of remittance might not be the same across time periods, and a standard empirical test confirms this dynamic. Ignoring this dynamic, a pooled model reveals that remittance inflows have no effect on economic growth. However, when we account for the dynamics and estimate separate models accordingly, allowing for the effect of remittance to vary across sub-periods, we find that the positive effect of remittance inflows was not only marginally bigger when compared to the pooled model, but it also became important for economic growth. Though relevant for growth, it is worth noting that remittance is not yet a major source of economic growth as the effect is still quite marginal.

Keywords: Dynamics, economic growth, endogeneity, instruments, remittance inflows, 2SLS

JEL Classification: E2, F24, O11, O40

DOI: $10.15611 /$ aoe.2015.2.04

\section{INTRODUCTION}

Since the 1980s, the microeconomics of remittances has been structured towards the role of information and social interactions in explaining transfer behaviour while the macroeconomics aspect concentrated on the short-term effects of international transfer within the framework of static trade models. Gradually, the focus has shifted to the long-term effects which look at the role of remittances within the dynamics of inequality and development. This study concentrates on developing countries, using Nigeria as a case study because the context in which remittances take place for developing countries is unique since they are characterized with high levels of poverty, inequality and income volatility, imperfect capital markets and liquidity constraints which hinder investment in migration and education. As it stands today, remittances inflow which represents transfers from international migrants to family members, relatives and friends in their home country or country of

\footnotetext{
* Department of Economics, University of Nigeria, Nigeria
} 
origin accounts for a significant portion of the total financial inflows to most developing nations in the world. Remittances are becoming a very important source of foreign financial flows, especially in developing countries, both in size and growth rate, exceeding the inflows of most forms of financial flows. The true size of remittances, as well as unrecorded flows through formal and informal channels, is believed to be significantly large (Gammeltoft, 2002; Ratha, 2007) as cited in Ukeje and Obiechina (2013).

Therefore the size and importance of remittance inflows into developing countries cannot be overemphasized. To buttress this fact, the World Bank estimates that migrants remitted $\$ 401$ billion in 2012, and projects that by 2015 this figure could grow by another $\$ 114$ billion, representing about 28 percent growth within a space of three years. It is worthnoting that in 2011, migrants sent approximately three times more to developing countries than these countries received in official development assistance; and they sent an amount equal to about half of the foreign direct investment (FDI) in these countries (World Bank, 2013). In some developing and emerging economies, remittances inflow represents more than 20 percent of the gross domestic product (GDP), and this is just what can be measured. The actual amounts may be much higher, as money sent through informal channels often goes unrecorded (Ratha, 2013). To lay credence to the aforementioned, the World Bank (2013) in its Migration and Development Brief 20 noted that India, China the Philippines, Mexico and Nigeria received the greatest amount of migrant remittances of all the countries in the world in 2012, accepting a combined $\$ 197$ billion, or nearly half of all the monies remitted to the developing world that year. As shown in Figure 1, India received the highest inflows of remittances in the world as at 2012, receiving a total sum of $\$ 70$ billion. Following closely is China, with $\$ 66$ billion in remittance inflows. Remittances received stood at $\$ 24$ billion for both the Philippines and Mexico, while Nigeria followed closely with $\$ 21$ billion.

Remittance inflows into the Nigerian economy have grown tremendously over the years. In 1977, Nigerian migrants remitted only \$20million, but as of 2012 , the remittance inflows increased greatly to $\$ 21$ billion. Table 1 summarizes the remittance inflows into the Nigerian economy from 1977-2012 .

Basically, the majority of remittance inflows into Nigeria are expended on the necessities of life. In other words, most of the remitted funds go into direct consumption - food, clothing, shelter and health. Such consumption financed by remittance inflows helps to lift huge numbers of people out of poverty by supporting a higher level of consumption than would otherwise 


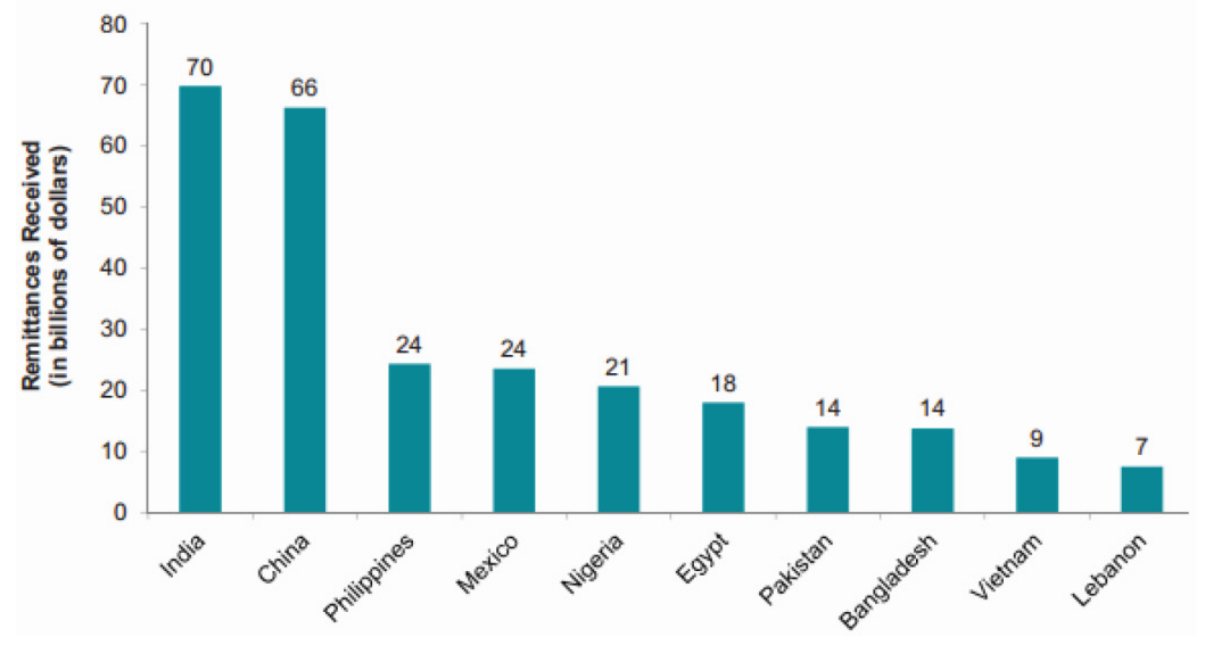

Figure 1. Top Remittance Recipient Countries, 2012

Source: Ratha and Timmer, "Outlook for Migration and Remittances 2013-2015"

Table 1

Remittance Inflows into Nigeria

\begin{tabular}{c|c|c|c|c|c}
\hline Year & Value $\mathbf{( \$ )}$ & \% of GDP & Year & \multicolumn{1}{c}{ Value (\$) } & \% of GDP \\
\hline 1977 & $20,000,000$ & 0.06 & 1995 & $804,000,000$ & 2.86 \\
\hline 1978 & $3,000,000$ & 0.01 & 1996 & $947,000,000$ & 2.68 \\
\hline 1979 & $8,000,000$ & 0.02 & 1997 & $1,920,000,000$ & 5.30 \\
\hline 1980 & $22,000,000$ & 0.03 & 1998 & $1,544,000,000$ & 4.80 \\
\hline 1981 & $16,000,000$ & 0.03 & 1999 & $1,301,000,000$ & 3.74 \\
\hline 1982 & $18,000,000$ & 0.04 & 2000 & $1,391,800,000$ & 3.03 \\
\hline 1983 & $14,000,000$ & 0.04 & 2001 & $1,166,600,000$ & 2.43 \\
\hline 1984 & $12,000,000$ & 0.04 & 2002 & $1,208,900,000$ & 2.04 \\
\hline 1985 & $10,000,000$ & 0.04 & 2003 & $1,062,800,000$ & 1.57 \\
\hline 1986 & $4,000,000$ & 0.02 & 2004 & $2,272,700,000$ & 2.59 \\
\hline 1987 & $3,000,000$ & 0.01 & 2005 & $14,640,090,000$ & 13.04 \\
\hline 1988 & $2,000,000$ & 0.01 & 2006 & $16,932,360,000$ & 11.64 \\
\hline 1989 & $10,000,000$ & 0.04 & 2007 & $18,011,300,000$ & 10.86 \\
\hline 1990 & $10,000,000$ & 0.04 & 2008 & $19,205,910,000$ & 9.27 \\
\hline 1991 & $66,000,000$ & 0.24 & 2009 & $18,368,330,000$ & 10.90 \\
\hline 1992 & $56,000,000$ & 0.17 & 2010 & $19,817,840,000$ & 8.67 \\
\hline 1993 & $793,000,000$ & 3.71 & 2011 & $20,618,850,000$ & 8.45 \\
\hline 1994 & $550,000,000$ & 2.32 & 2012 & $21,000,000,000$ & 4.57 \\
\hline
\end{tabular}

Source: World Bank, Index Mundi and author's computation 
be possible. This effect is widely recognized (Barajas et al., 2009). Having noted that remittance inflows help to improve the standard of living at micro level in a developing nation like Nigeria, there is also the need to empirically examine and correctly understand if these micro benefits have been translated into long-term macroeconomic benefits on the economy as a whole, since improved household consumption is expected to raise aggregate demand in the economy. Therefore the purpose of this study is to empirically establish how remittance inflows affect the Nigerian economy at macro level using quarterly time series data from 1977-2012. Almost all the previous studies carried out in Nigeria to investigate remittance inflows employed annual time-series data (Agu, 2009; Udah, 2011; Ukeje and Obiechina, 2013). Quarterly data have some recognized advantages over its annual counterpart in this scenario. For instance, since remittances decisions are taken throughout the year and are often based on (preliminary) weekly, monthly and quarterly information, using quarterly data will allow us to better capture important intra-year dynamics, rather than using annual data. More importantly, the issue of endogeneity that previous studies in Nigeria have ignored will be addressed. The rest of the paper is outlined as follows section two reviews various related literature, section three discusses the data pre-test and methodology, section four presents the empirical results and analysis and section five provides the conclusions.

\section{REVIEW OF LITERATURE}

\subsection{Theoretical Review}

There are some theories that give insight into migration and remittances and how they affect an economy, some of these theories are examined below.

\section{Neo-classical Migration Theory}

Strictly speaking, the neo-classical migration theory completely jettisoned the possibility for any form of gain for non-migrants. In other words, neoclassical migration theory therefore has no place for financial remittances inflows to home countries (Taylor, 1999:65). Neo-classical migration theory sees migrants as self-seeking utility maximizing individuals. The theory disregards other migration motives as well as migrants belonging to social groups such as households, families and communities. 


\section{Developmentalist Migration Theory}

The central idea of the 1950s and 1960s in development theory was that return migrants were important agents of innovation and change. Consequently, it was expected that migrants not only bring back money, but also new ideas, knowledge, and entrepreneurial ideas. By so doing, migrants were expected to play a positive role in development and contribute to the accelerated spatial diffusion of modernization in developing countries. Also, the developmentalist migration theory attributed to remittances an important role in stimulating economic growth. For instance in the post-war period, large-scale labour migration from developing to developed countries started to gain momentum. Many countries with excess labour became involved in the migration process amidst expectations of the dawning of a new era (Papademetriou, 1985:212). Governments of developing countries, for instance in the Mediterranean, started to actively encourage their citizens to leave and live in other developed countries, which they considered as one of the principal instruments to promote development in their home country (Adler, 1981; Penninx, 1982; Heinemeijer et al., 1977).

\section{Cumulative Causation Migration Theory}

This theory took a pessimistic view of migration. Here, migration was seen as worsening the problems of underdevelopment in developing countries. As posited by Papademetriou (1985), by sending to developing countries, emigration would bring about "the evolution into an uncontrolled depletion of their already meagre supplies of skilled manpower - and the most healthy, dynamic, and productive members of their populations". This brain drain, if not checked, will in no small measure hinder the developmental strides of the developing countries. The cumulative causative theory believes that migration undermines regional and local economies by depriving communities of their most valuable labour force, increasing their dependence on developed countries. According to Baldwin (1970), emigration is perceived to deprive poor countries of their scarce skilled and professional labour resources in which states have invested many years of education. This kind of skilled manpower exodus is not good for any developing nation hoping to be developed one day.

\section{The New Economics for Labour Migration}

Under this new approach, the behaviour of an individual migrant was viewed or seen in a broader context, and basic decision making was placed 
on the shoulders of the household as opposed to the individual (Stark 1978, 1991), played a key role in rejuvenating this thinking pattern as it concerns migration. This new approach sees migration as the risk-sharing behaviour of households. Better than individuals, households seem able to diversify their resources such as labour, in order to minimize income risks (Stark and Levhari, 1982). The crux of the new economic for labour migrants is that for households as a whole, it may be a Pareto-superior strategy to have members of the family migrate elsewhere, either as a means of risk sharing and/or as an investment in accessing higher earnings streams (Lucas and Stark, 1985:902).

\subsection{Empirical Review}

Several studies have been carried out to examine the role of remittance inflows in achieving economic growth and development, prompting considerable debate in this regard. Some authors insist that remittance does more harm than good to the receiving countries, while others noted that remittance inflows actually help to improve economic performance. This shows a clear absence of consensus on the role of remittance inflows on the receiving economy. For the purpose of symmetry, some of those previous studies will be summarily grouped into negative and positive outcomes.

\section{Negative Outcomes}

Chami et al. (2005) developed a model of remittances based on the economics of families and found that remittance is more compensatory transfers, not profit driven and thus possess a negative correlation with GDP growth. Also, adopting the instrumental variables approach to account for endogeneity, Spatafora (2005), finds no statistically significant link between remittances and per capita output growth for up to 101 countries over the period 1970 to 2003. Furthermore, Barajas et al. (2009), using the OLS fixed effect instrumental variable model for 84 recipient countries with an annual observations for 1970-2004,reveals that decades of private income transfersremittances-have contributed little to economic growth in remittancereceiving economies and may have even retarded growth in some. They further noted that when remittances are properly measured, and when the growth equations are well specified and instrumented, there is really no significant positive impact of remittances on long-term growth, and often find a negative relationship between remittances and growth. 
In addition, Siddique and Selvanathan (2010) investigated the causal link between remittances and economic growth in three countries, Bangladesh, India and Sri Lanka, by employing the Granger causality test under a VAR framework. Using time series data over a 25 year period, they find that growth in remittances does lead to economic growth in Bangladesh as well as in India. Lipton (1980), Lewis (1986), Ahlburg (1991) and Brown and Ahlburg (1999), all argued that migration and remittances weaken productivity and growth in low-income countries because they are readily spent on consumption likely to be dominated by foreign goods than on productive investments. Also, other authors confirm the supposition that migration and remittances do not necessarily lead to the development of developing countries, but rather contribute to the development of underdevelopment in developing countries (Rhoades, 1979; Almeida, 1973; Rubenstein, 1992; Reichert, 1981; Binford, 2003).

\section{Positive Outcomes}

Kindleberger (1965) noted that large scale emigration and remittances can bring about rapid economic growth in both the country of immigration and the country of origin, depicting a win-win situation for both countries. Likewise, Beijer (1970) concludes that emigrants and their remittances represent a hope for the industrial development of their home country. In addition, Keely and Tran (1989) asserted that remittances would improve income distribution and quality of life beyond what other available development approaches could deliver. Catrinescu et al. (2006), using a dynamic panel analysis model examined remittances, institutions and economic growth for approximately 162 countries. The authors found that remittances exert a positively weak impact on macroeconomic growth. The study therefore concludes that the longer-term developmental impact of remittances is increased in the presence of sound economic policies and institutions. Also, Shera and Meyer (2013) investigated remittances and their impact on economic growth, employing a panel data set for 21 developing countries during the period of 1992-2012, while adopting the quasi fixed effect model for analysis. The results show that remittances do have a positive impact on economic growth. Feeny et al., (n.d.) conducted an econometric analysis using 136 developing countries data from 1971 to 2010 and this included 25 Small Island Developing States. They used a two-step system Generalized Method of Moments approach to remove the endogeneity problem of remittances. They found no association between 
remittances and per capital GDP for countries which are not classified as SIDS, but there was a positive association for SIDS countries.

Using the autoregressive distributive lag (ARDL) model, Udah (2011) investigated remittances, human capital and the economic performance in Nigeria. The results showed that remittances affect economic performance in Nigeria through its interaction with human capital and technology diffusion. The study therefore concludes that for Nigeria to benefit from international transfers, policies should be fine-tuned to attract more remittances into the educational sector and technological transfers. Ukeje and Obiechina (2013) used a time series data from 1970-2010 in an error correction methodology (ECM) to investigate the empirical impact of workers' remittances on economic growth in Nigeria. The authors found a significant positive relationship between workers' remittances and economic growth. Consequently, the authors recommend the need to provide an adequate infrastructure for attracting more remittances into the economy through a formal financial sector channel as well as measures encouraging the recipients to channel such into the productive sector or through domestic savings that would boost investment and economic growth, rather than become enmeshed in non-productive activities.

\section{DATA PRE-TEST AND METHODOLOGY}

Since this study is set out to model the relationship among a given set of time-series variables, it is pertinent to carry out some pre-test on the variables of interest so as to be appropriately guided in the model specification. The four variables of interest are briefly described as follows; real gross domestic product (RGDP), remittance inflows (REM), foreign direct investment (FDI) and private investment (PI).

\subsection{Stationarity Test}

The Augmented Dickey Fuller (ADF) and the Phillips Perron (PP) tests of stationarity will be employed to determine the underlying properties of that process that generated the time series, that is, whether the variables of interest have unit root or not. The results of the stationarity test are presented in Table 2. As shown in Table 2, both the ADF and PP test indicate that the variables of interest are not stationary at a level form; rather, they are all stationary or integrated at first difference. Hence, the null hypothesis of unit root is rejected for all the variables at the $1 \%$ level of significance. 


\subsection{Cointegration Test}

It is expected that a regression analysis that model the relationship among a given set of non-stationary time series (i.e. not stationary at level) will generate spurious (i.e. non-meaningful) regression estimates. However, if a long-term relationship can be established among such variables, their estimates become meaningful even if the variables are not $\mathrm{I}(0)$. A cointegration test is one sure way of establishing the presence or absence of such a long-term relationship. Economically speaking, two or more variables will be cointegrated if they have a long-term or an equilibrium relationship between or among them (Gujarati, 2004:822). The Johansen (1991) likelihood ratio test statistics, the trace and maximal eigenvalue test statistics, will be utilized to determine the number of cointegrating vectors since all the variables are I(1). The results are presented in Table 3. The results in Table 3 reveal that both the trace and maximal eigenvalue test statistics reject the null hypotheses of zero cointegrating vector and one cointegrating vectors leading to the conclusion that two cointegrating vectors

Table 2

Stationarity Test

\begin{tabular}{l|c|c|c|c|c|c}
\hline \multirow{2}{*}{ Variable } & \multicolumn{3}{|c|}{ Augmented Dickey-Fuller } & \multicolumn{3}{c}{ Phillips-Perron } \\
\cline { 2 - 7 } & $\begin{array}{c}\text { Test } \\
\text { Statistic }\end{array}$ & $\begin{array}{c}\mathbf{0 . 0 1} \text { Critical } \\
\text { Value }\end{array}$ & Integration & $\begin{array}{c}\text { Test } \\
\text { Statistic }\end{array}$ & $\begin{array}{c}\text { 0.01 Critical } \\
\text { Value }\end{array}$ & Integration \\
\hline RGDP & -6.291 & -3.477 & $\mathrm{I}(1)$ & -6.046 & -3.477 & $\mathrm{I}(1)$ \\
\hline REM & -4.093 & -3.477 & $\mathrm{I}(1)$ & -4.053 & -3.477 & $\mathrm{I}(1)$ \\
\hline FDI & -4.555 & -3.477 & $\mathrm{I}(1)$ & -4.168 & -3.477 & $\mathrm{I}(1)$ \\
\hline PI & -6.469 & -3.477 & $\mathrm{I}(1)$ & -5.304 & -3.477 & $\mathrm{I}(1)$ \\
\hline
\end{tabular}

Source: authors' estimation

Table 3

Johansen Cointegration Test

\begin{tabular}{c|c|c|l|c|c|c}
\hline \multirow{2}{*}{$\mathbf{H}_{\mathbf{0}}$} & \multicolumn{3}{|c|}{ Trace } & \multicolumn{3}{c}{ Maximum Eigenvalue } \\
\cline { 2 - 7 } & $\begin{array}{c}\text { Trace } \\
\text { Statistic }\end{array}$ & $\begin{array}{c}\mathbf{0 . 0 5} \text { Critical } \\
\text { Value }\end{array}$ & Probability & $\begin{array}{c}\text { Max-Eigen } \\
\text { Statistic }\end{array}$ & $\begin{array}{c}\text { 0.05 Critical } \\
\text { Value }\end{array}$ & Probability \\
\hline $\mathrm{r}=0$ & 115.19 & 47.856 & $0.0000^{* *}$ & 62.951 & 27.584 & $0.0000^{* *}$ \\
\cline { 2 - 7 } $\mathrm{r}=1$ & 52.244 & 29.797 & $0.0001^{* *}$ & 39.487 & 21.132 & $0.0001^{* *}$ \\
\cline { 2 - 7 } $\mathrm{r}=2$ & 12.757 & 15.494 & 0.1240 & 12.670 & 14.265 & 0.0880 \\
$\mathrm{nyyyyyy}=3$ & 0.0871 & 3.8415 & 0.7678 & 3.8415 & 3.8415 & 0.7678 \\
\hline
\end{tabular}

Note: ** denotes rejection of the null hypothesis at the $5 \%$ level of significance and $\mathrm{r}$ represents the number of cointegrating vectors.

Source: authors' estimation 
exist among the variables of interest since the null of two cointegrating vectors cannot be rejected. Since the variables are cointegrated, there is therefore a long-term or equilibrium relationship among them. Therefore, the relationship among the variables of interest can be modelled at their level form.

\subsection{Model Specification}

Having established the presence of a long-term relationship, our variables of interest can therefore be modelled in level form:

$$
\ln r g d p_{t}=\alpha+\lambda r e m i_{t}+\delta f d i_{t}+\beta p i_{t}+\mu_{t},
$$

where $\ln r g d p$ is the natural log of real gross domestic product, a proxy for economic growth, remi is remittance inflows, $f d i$ is foreign direct investment, $p i$ is private investment, $\alpha, \lambda, \delta$ and $\beta$ are unknown parameters to be estimated, $\mu$ is the error or disturbance term and $t$ represents the current time period. Variables $f d i$ and $p i$ are chosen as control variables because they are relevant in explaining economic growth under the context of remittance inflows. A conceivable problem that could arise in equation (1) above is the problem of endogeneity as remi is expected to be correlated with the error term. This is possible because, to some extent, remittance inflows can be influenced by growth in the economy as poorer countries or countries experiencing less success in economic growth are more likely to receive larger amount of remittance inflows. This issue of reverse causality has been widely acknowledged in the literature and adequately addressed through the use of instruments (see Spatafora, 2005; Catrinescu et al., 2006; Singh et al., 2010; Thanh, 2008; Barajas et al., 2009). Unlike the aforementioned, most previous studies in Nigeria have ignored this problem of endogeneity (Agu, 2009; Udah, 2011; Ukeje and Obiechina, 2013). In order to avoid biased estimates which ordinary least square (OLS) will give in the face of endogeneity, remittancinflows will be instrumentalized with its first lagged level ( $\left.r e m i_{t-1}\right)$ and the two stage least squared (2SLS or TSLS) technique will be employed.

The first lagged value of remi $\left(\right.$ remi $\left._{t-1}\right)$ is chosen as an instrumental variable (IV) because it satisfies the two assumptions that guide the application of IV: firstly, remi $i_{t-1}$ is uncorrelated with $\mu_{t}$, that is, $\operatorname{Cov}\left(\right.$ remi $\left._{t-1}, \mu_{t}\right)=0$, since the current growth of the economy cannot predict or determine the last year's remittance. Thus, remi $i_{t-1}$ can be argued to be 
orthogonal to the error term $\mu_{t}$. Secondly, remi $i_{t-1}$ is correlated with remi $t_{t}$, that is, $\operatorname{Cov}\left(\right.$ remi $\left._{t-1}, \mu_{t}\right) \neq 0$ since the pair-wise correlation between them is very high. ${ }^{1}$ Having established the validity of our instrument, 2SLS can then be applied. As the name suggests, 2SLS has two stages or two regressions: (1) we first separate or isolate the part of remi $i_{t}$ that is not correlated with $\mu_{t}$ by regressing remi $\mathrm{remi}_{t}$ on remi $i_{t-1}$ and every other exogenous variables in equation (1), using OLS:

$$
\operatorname{remi}_{t}=\alpha+\psi r e m i_{t-1}+\delta f d i_{t}+\beta p i_{t}+v_{t} .
$$

The next thing is to compute the predicted or fitted values of remi, $\widehat{r e m i} i_{t}$, where $\widehat{r e m i} i_{t}=\hat{\alpha}+\hat{\psi} r e m i_{t-1}+\hat{\delta} f d i_{t}+\hat{\beta} p i_{t}$. (2) We replace remi $i_{t}$ by $\widehat{r e m i}_{t}$ in the second and last regression:

$$
\ln r g d p_{t}=\alpha+\lambda \widehat{r e m i} i_{t}+\delta f d i_{t}+\beta p i_{t}+\mu_{t} .
$$

It can therefore be seen that although remi in equation (1) is correlated or likely to be correlated with the error term $\mu_{t}$ (hence rendering OLS inappropriate in that regard), $\widehat{r e m i}_{t}$ in equation (3) is uncorrelated with the error term $\mu_{t}$ asymptotically, that is, as the sample size increases indefinitely. Hence, OLS can be applied to (3) and the resulting estimate, $\lambda$ is called the 2SLS estimate and it is a consistent estimate.

\subsection{Dynamics}

A simple plot of the remittance variable reveals the following.

The above figures reveal different regularities in the inflow of remittance, suggestive of possible dynamics in the effect of remittance on economic growth over the periods under review. A massive upsurge of inflow is observed from 2005 in the annual data, which corresponds to the 112th quarter in the quarterly series. This suggests that we might need to analyze the effect of remittance in two sub-periods: 1977-2004 and 2005-2012 in the case of annual data; 1977Q1-2014Q4 and 2005Q12012Q4 for the quarterly. We will focus on the quarterly series for the purpose of this study as earlier noted. If this suggestion is correct, this

\footnotetext{
${ }^{1}$ Actually the estimated value is 0.993 .
} 


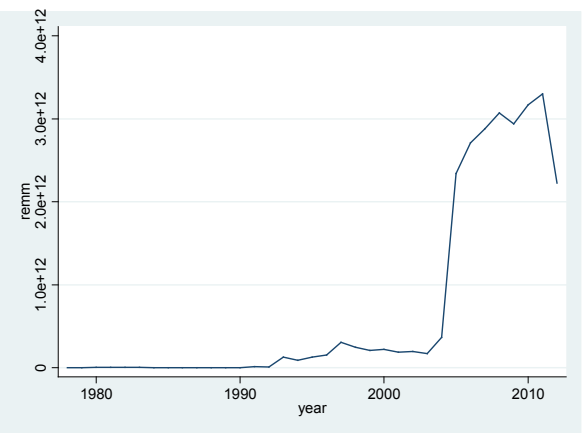

Figure 2. Annual Remittance Inflow

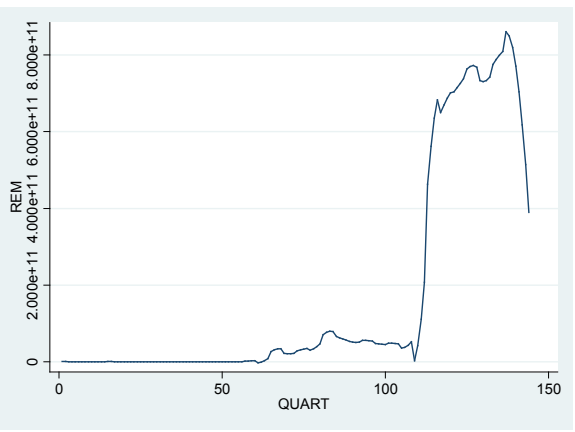

Figure 3. Quarterly Remittance Inflow

will mean estimating two separate equations. That is, estimating equation (3) for both sub-periods instead of a singled pooled equation. A standard Chow test that follows from the $F$ test procedure can be used to test this assertion empirically. The null hypothesis under test is that the effect of remittance is the same across the sub-periods, hence a single equation will suffice. A rejection of the null favours the estimation of two separate equations, indicating dynamics in the effect of remittance. The test statistic is given as follows:

$$
\begin{gathered}
F_{c a l}=\frac{\left(R S S_{R}-R S S_{U R}\right) / k}{\left(R S S_{U R}\right) /\left(n_{1}+n_{2}-2 k\right)} \sim F\left[k,\left(n_{1}+n_{2}-2 k\right)\right] \\
F_{c a l}=\frac{(69.357-55.702) / 4}{(55.702) / 135}=8.3 \sim F(4,143) .
\end{gathered}
$$

The $F$ statistic's critical value at the 0.05 significance level is 2.372 . The null hypothesis that suggests that the effect of remittance is the same across sub-periods is decisively rejected. This implies that there is indeed some dynamics in the effect of remittance on economic growth as suggested by Figures 2 and 3. Thus, estimating a single equation like equation (3) for all the time periods (pooled) will not reveal the true effect of remittance. Rather, estimating equation (3) for both the observed sub-periods will do better under this circumstance. In other words, two separate equations will fit the remittance data better than a single pooled equation. A simple plot of the real gross domestic product is also presented in Figures 4 and 5 below. 


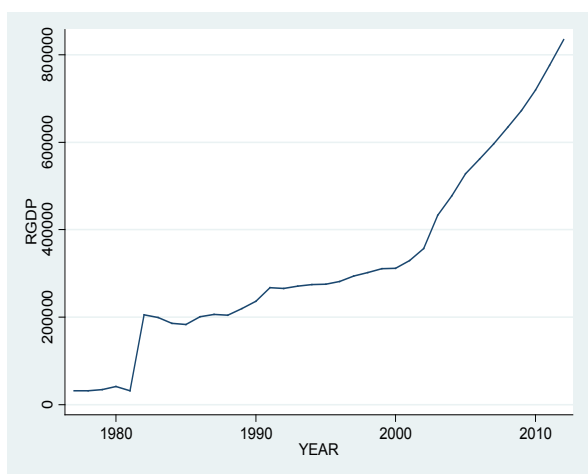

Figure 4. Annual Real Gross Domestic Product

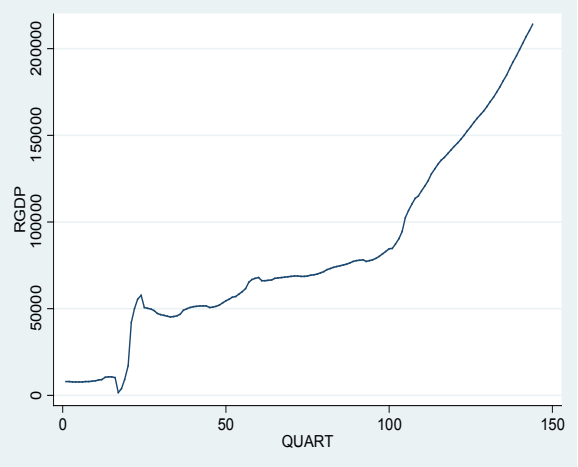

Figure 5. Quarterly Real Gross Domestic Product

Real gross domestic product took off from around 1981 (about the 17th quarter under review) and maintained a relatively steady growth compared to remittance inflow. We have less dynamics here.

\section{EMPIRICAL ESTIMATES}

Using 2SLS, we first estimate equation (3) for the whole periods, ignoring the observed dynamics and thus constraining the effect of remittance to be the same in all periods. The results are summarized in Table 4. The estimate of remittance, the variable of interest, shows that remittance inflow has no

Table 4

Estimates of equation (3)for the whole periods (pooled)

\begin{tabular}{|c|c|c|}
\hline Endogenous variable & Exogenous variables & Coefficients \\
\hline \multirow[t]{4}{*}{$\ln r g d p$} & $\widehat{\text { remi }_{t}}$ & $\begin{array}{l}0.00000000000065 \\
(0.90)\end{array}$ \\
\hline & $f d i$ & $\begin{array}{l}0.0000029 \\
(1.33) \\
\end{array}$ \\
\hline & $p i$ & $\begin{array}{l}0.223887^{* * * *} \\
(3.54) \\
\end{array}$ \\
\hline & constant & $\begin{array}{l}9.4694550 * * * \\
(27.54)\end{array}$ \\
\hline
\end{tabular}

Note: The values in bracket represent $\mathrm{t}$-values, while $* * *$ denotes statistically significant at $1 \%$ level of significance

R-squared: 0.4300

Source: authors' estimation 
effect on economic growth in Nigeria, that is, the estimated parameter of the remittance inflow variable is statistically insignificant. This result might be due to the restriction a single equation imposed on the effect of remittance, especially as the findings in section 3.4 suggest two separate equations. Therefore, we estimated equation (3) again, but this time for the two subperiods (1977Q1-2014Q4 and 2005Q1-2012Q4), allowing the effects of remittance to vary across the sub-periods where a major break was observed. The estimates are summarized in Tables 5 and 6.

Table 5

Estimates of equation (3) for 1971Q1-2004Q4 (First sub-period)

\begin{tabular}{l|l|l}
\hline Endogenous variable & Exogenous variables & \multicolumn{1}{c}{ Coefficients } \\
\hline $\ln r g d p$ & $\widehat{\widehat{r e m i}_{t}}$ & $\begin{array}{l}0.0000000000091^{* *} \\
(2.04)\end{array}$ \\
\hline & $f d i$ & $\begin{array}{l}0.0000066 \\
(1.31)\end{array}$ \\
& \multirow{2}{*}{ pi } & $\begin{array}{l}0.1768873^{* *} \\
(2.44)\end{array}$ \\
\hline & \multirow{2}{*}{ constant } & $\begin{array}{l}9.4599820^{* * *} \\
(24.46)\end{array}$ \\
\hline
\end{tabular}

Note: The values in bracket represent $t$-values, while $* *$ and $* * *$ denote statistically significant at $5 \%$ and $1 \%$ level of significance, respectively.

R-squared: 0.3202

Source: authors' estimation

Table 6

Estimates of equation (3) for 2005Q1-2012Q4 (Second sub-period)

\begin{tabular}{l|l|l}
\hline Endogenous variable & Exogenous variables & \multicolumn{1}{c}{ Coefficients } \\
\hline $\ln r g d p$ & $\widehat{r e m i} i_{t}$ & $\begin{array}{l}0.00000000000103^{*} \\
(1.70)\end{array}$ \\
\hline & $f d i$ & -0.0000007 \\
& & $(0.57)$ \\
\hline & \multirow{2}{*}{ pi } & $\begin{array}{l}0.0470694 \\
(1.22)\end{array}$ \\
\hline & \multirow{2}{*}{ constant } & $\begin{array}{l}1.08398^{* * *} \\
(25.94)\end{array}$ \\
\hline
\end{tabular}

R-squared: 0.1904

Note: The values in bracket represent $t$-values, while * and *** denote statistically significant at 10 and $1 \%$ level of significance, respectively

Source: authors' estimation 
The results in Table 5, the first sub-period, show that the remittance estimate is marginally bigger than the estimate obtained when we use the constrained model. More importantly, the positive effect of remittance estimate on economic growth, though small, is now statistically significant. Turning to the results in Table 6 , the second sub-period, the results also return a positive and significant effect of remittance estimate on economic growth and are also marginally bigger than that of the constrained model. These results from estimating two separate equations therefore indicate that a single pooled model might not accurately explain the effect of remittance based and on the data used, thus underscoring the importance of accounting for the dynamics inherent in remittance inflows in Nigeria. Contrary to the results from the pooled model which suggest that remittance inflow does not matter in explaining economic growth in Nigeria, the estimates from the two separate equations that recognized the dynamism in remittance inflow within the periods under review show that indeed, remittance inflows matter for economic growth in Nigeria.

The latter results that account for dynamics are more intuitive since household consumption, a key component of aggregate demand, are known to be positively driven by remittance inflows in developing countries (Barajas et al., 2009). However, the effect of remittance is still quite marginal in explaining economic growth in Nigeria.

\section{CONCLUSIONS}

Remittance inflow is fast becoming an important source of household income in developing countries. This raises the need to assess its effect on the economy as a whole. This study therefore analyzed the role of remittance in the Nigerian economy, using quarterly data. We observed some dynamics in remittance inflow within the periods under review. For instance, the share of remittance in RGDP rose substantially in 1993 and 2005. This could be attributed to the high rise in remittance inflow within these periods. In 2012 the share of remittance in RGDP reduced substantially. This is explained by the high rise in RGDP within this period. A closer look at remittance inflow into Nigeria reveals a major upsurge as from 2005, corresponding to the 112th quarter under review. This therefore suggests that the effect of remittance might not be the same across periods, requiring sub-periods estimation. A standard Chow test confirms this dynamic. Aware that a remittance variable is likely to be endogenous in a growth model because of reverse causality, we use the 2 SLS estimation procedure to address the 
endogeneity problem which has been ignored by most previous studies in Nigeria. Ignoring for a moment the observed dynamics and constraining the effect of remittance to be the same in all the periods observed, we find that remittance plays no role in Nigeria's economic growth. However, when we allow the effect of remittance to vary across sub-periods based on the observed upsurge (1977Q1-2014Q4 and 2005Q1-2012Q4) and estimate two separate equations for each sub-periods, the effect of remittance was not only marginally bigger when compared to the pooled model, but it also became important for economic growth. Thus, by accounting for dynamics, we get a more meaningful and intuitive result. Though relevant for growth, it is worth noting that remittance inflow is not yet a major source of economic growth in Nigeria as the effect is still quite marginal.

\section{REFERENCES}

Adler, S., A Turkish Conundrum: Emigration, Politics and Development. ILO, Geneva, 1981.

Agu, C., Remittances for Growth: A Two Fold Analysis of Feedback between Remittances, Financial Flows and the Real Economy in Nigeria. A paper presented at the African Econometric Conference (AERC) in Nigeria, 2009.

Ahlburg, D., Remittances and their Impact: A study of Tonga and Samoa. Pacific Pol. Paper No. 7, Canberra, The Australian National University, 1991.

Almeida, C., 1973 Emigration, Espace et Sous-Développement, "International Migration", 13, pp. 112-1.

Baldwin, G., Brain Drain or Overflow, "Foreign Affairs", 48, pp. 358-372, 1970.

Barajas, et al., 2009, Do Workers' Remittances Promote Economic Growth?, "International Monetary Fund Working Paper" WP/09/153, 2009.

Beijer, G., 1970, International and National Migratory Movements, "International Migration", 8, pp. 93-109, 1970.

Binford, L., Migrant Remittances and (Under)development in Mexico, "Critique of Anthropology", 23, pp. 305-336, 2003.

Brown, R., Ahlburg, D., Remittances in the South Pacific, "International Journal of Soc. Econ.”, 26, pp. 325-344, 1999.

Catrinescu, et al., Remittances, Institutions and Economic Growth. The Institute for the Study of Labor (IZA) discussion paper, IZA DP No. 2139, 2006.

Chami, R., Fullenkamp, C., Jahjah, S., Are immigrant remittance flows a source of capital for development, "International Monetary Fund Staff Papers", 52, pp. 55-81, 2005.

Feeny, S., Iamsiraroj, S., McGillivray, M., n.d., Remittances and Economic Growth: Larger Impacts in Smaller Countries?, s.l.: Alfred Deakin Research Institute.

Gammeltoft, Remittances and Other Financial Flows to Developing Countries, "International Migration", 40, pp. 181-211, 2002.

Gujarati, D. N., Basic Econometrics (4th ed.). Mcgraw-Hill Publishing, New York, 2004. 
Heinemeijer, et al., Partir pour rester, une enquête sur les incidences de l'émigration ouvrière à la campagne marocaine. NUFFIC, Den Haag, 1977.

Johansen, S., Estimation and Hypothesis Testing of Cointegration Vectors in Gaussian Vector Autoregressive Models, "Econometrica", 59, pp. 1551-1580, 1991.

Keely, C., Tran, B., Remittances from Labor Migration: Evaluations, Performance, and Implications, "International Migration Review", 23, pp. 500-525, 1989.

Kindleberger, C., Europe's Postwar Growth: The Role of Labor Supply. Oxford University Press, New York, 1965.

Lewis, J. R., International Labour Migration and Uneven Regional Development in Labour Exporting Countries. "Tijdschrift Voor Economische En Sociale Geografie", 77, pp. 2741, 1986.

Lipton, M., Migration from the Rural Areas of Poor Countries: The Impact on Rural Productivity and Income Distribution, "World Development", 8, pp. 1-24, 1980.

Lucas, R., Stark, O., Motivations to Remit: Evidence from Botswana, "Journal of Political Economy”, 93, pp. 901-918, 1985.

Papademetriou, D., Illusions and Reality in International Migration: Migration and Development in post-World War II Greece, "International Migration", 23, pp. 211-223, 1985.

Penninx, R., A Critical Review of Theory and Practice: The Case of Turkey, "International Migration Review", 16, pp. 781-818, 1982.

Ratha, D., Leveraging Remittances for Development. Policy Brief, "Migration Policy Institute", Washington DC, 2007.

Rather, D, The Impact of Remittances on Economic Growth and Poverty Reduction, "Migration Policy Institute", Policy Brief., 2013.

Rather and Timmer, Outlook for Migration and Remittances 2013-2015 (PowerPoint presentation of the World Bank Development Prospects Group, Washington, DC, April 19, 2013).

Reichert, J., The Migrant Syndrome: Seasonal U.S. Labor Migration and Rural Development in Central Mexico, "Human Organization", 40, pp. 56-66, 1981.

Rhoades, R., From Caves to Main Street: Return Migration and the Transformations of a Spanish Village, "Papers in Anthropology", 20, pp. 57-74, 1979.

Rubenstein, H., Migration, Development and Remittances in Rural Mexico, "International Migration", 30, 1992.

Shera, A., Meyer, D., Remittances and Their Impact on Economic Growth, "Social and Management Sciences", 21, pp. 3-19, 2013.

Siddique, A., Selvanathan, E., Saroja, S., Remittances and Economic Growth: Empirical Evidence from Bangladesh, India and Sri Lanka, The University of Western Australia, Discussion Paper 10.27, 2010.

Singh, et al., Determinants and Macroeconomic Impact of Remittances in Sub-Sahara Africa, "Journal of Africa Economies", 20, pp. 312-340, 2010.

Spatafora, N., Worker Remittances and Economic Development, "World Economic Outlook" (April), pp. 69-84, 2005. 
Stark, O., Economic-Demographic Interactions in Agricultural Development: The Case of Rural-to-Urban Migration. FAO, Rome, 1978.

Stark, O., The Migration of Labour. Blackwell, Cambridge \& Oxford, 1991.

Stark, O., Levhari, D., On Migration and Risk in LDCs. Economic Development and Cultural Change, 31, pp. 191-196, 1982.

Thanh, L., Trade, Remittances, Institutions, and Economic Growth, Macroeconomics Research Group, School of Economics, University of Queensland, 2008.

Taylor, J. E., 1999, The New Economics of Labour Migration and the Role of Remittances in the Migration Process, “International Migration', 37, pp. 63-88, 1999.

Udah, E., Remittances, Human Capital and Economic Performance in Nigeria, "Journal of Sustainable Development in Africa”, 13, pp. 300-318, 2011.

Ukeje, E., Obiechina, M., Workers' Remittances - Economic Growth Nexus: Evidence from Nigeria, Using An Error Correction Methodology, "International Journal of Humanities and Social Science", 3, pp. 212-227, 2013.

Woodridge, J., Introductory Econometrics: A Modern Approach. South Western College Publishing, USA, 2005.

The World Bank, Migration and Development Brief 20 (The World Bank Development Prospects Group, Migration and Remittances Unit), 2013.

Received: July 2014, revised: April 2015 